日臨外会誌 $59(8), 1965-1969,1998$

原著

食道癌におけるリンパ節転移個数と予後に関する検討

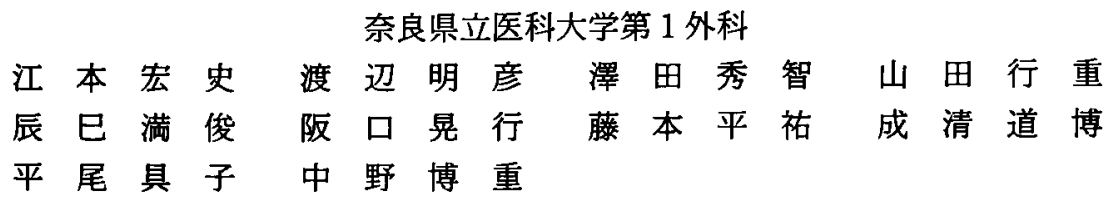

R2以上のリンパ節郭清を行った食道癌切除126例につき転移リンパ節群と転移個数の 予後に及浑す影響について検討し, 他の予後因子も含め多変量解析を行った. 生存率は, 転移リンパ節群別では $\mathrm{n} 2, \mathrm{n} 3$ 間で差を認め, 転移リンパ節個数別では, 0 個, $1 \sim 3$ 個, $4 \sim 7$ 個，8 個以上の 4 群としたところ，0 個，1〜3 個群間と 1 3 個, 4〜 7 個群 間で差を認めた。さらに, n1, n2症例間においても $1 \sim 3$ 個群は $4 \sim 7$ 個群に比へ有意 に差を認め転移りンパ節群が，比較的近位に留まっていても転移個数の多い症例は予後 不良であった。年齢, 性差, 肉眼型, 占居部位, 深達度, 転移りンパ節群, 転移リンパ 節個数の 7 因子の多変量解析では, 転移リンパ節個数が最も重みのある予後因子であっ た.

今回の検討より, 食道癌において転移リンパ節個数は, 予後に影響する重要な予後因 子と考えられた。

索引用語：食道癌転移リンパ節個数, Kaplan-Meier 法, Cox の比例ハザードモデル

\section{緒 言}

リンパ節転移は食道癌切除例の予後を決定する重要 な因子の1つであるが, その程度は現行の食道癌取扱 い規約”(以下規約と略す)では，リンパ節群分類によ る転移の範囲のみにより評価されている。最近, 種々 の癌腫において転移リンパ節個数も重要な予後因子と

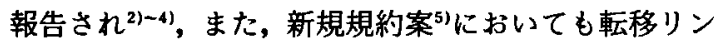
パ節個数が加味されている.そこで，今回，食道癌切 除例を対象に，食道癌のリンパ節転移群と転移個数の 関係拈よび，それらと予後の関係について検討した。

\section{対象と方法}

1983年 1 月より1996年12月までの13年間に R2以上 のリンパ節郭清を行った食道癌切除症例のうち, 手術 死，他病死，および他癌死を除いた126例につき転移り ンパ節群および転移リンパ節個数を中心に予後におよ ほすす影響について検討した。まず，各リンパ節群での 平均転移リンパ節個数の差の検定を分散分析（posthoc 法)により行った。次いで, 転移リンパ節群別, 転 移リンパ節個数別に予後解析を行った. 予後解析は,
Kaplan-Meier 法により累積生存率を算出し, 検定は Logrank 法により行った。さらに，予後に関すると考 えられる 7 因子につき Cox の比例ハザードモデルを 用い多変量解析を行い各因子の予後に対する重みを評 価した。統計学的有意差は $\mathrm{p}<0.05$ を有意差ありとし た。

\section{1) 対象の内訳}

対象となった患者の背景因子は，年龄は37歳から77 歳, 平均61.5歳で, 男女比は約 3：1であった。肉眼 型, 占居部位, 哚達度, 転移リンパ節群は表 1 に示す 通りであった。転移リンパ節個数は新規規約案 ${ }^{5)}$ に従 い 0 個 (42例)， $1 \sim 3$ 個 (42例)， $4 \sim 7$ 個 (26例), 8 個以上（16例）の4群に分類した（表 1 ).

\section{2）転移リンパ節群別の転移個数}

転移リンパ節群別の平均転移個数は, $\mathrm{n} 1$ が2.6個, $\mathrm{n} 2$ が3.8個, n3が6.9個, n4が12.5個で, n2, n3間 $(\mathrm{p}<0.05)$ と, n3，n4間 $(\mathrm{p}<0.01)$ に差を認め，遠位リンパ節群 への転移とともに転移個数は増加したが, n1, n2間で は差を認めなかった（図 1 )。

1998年 1月12日受付 1998 年 5 月12日採用 
表 1 背景因子

\begin{tabular}{|c|c|c|}
\hline 年齢 & \multicolumn{2}{|c|}{$37 \sim 77: 61.5 \pm 9.8$} \\
\hline \multirow[t]{2}{*}{ 性別 } & 男性 & $: 95$ \\
\hline & 女性 & $: 31$ \\
\hline \multirow[t]{5}{*}{ 肉眼型 } & 0 型 & $: 20$ \\
\hline & 1 型 & $: 14$ \\
\hline & 2 型 & $: 34$ \\
\hline & 3 型 & $: 51$ \\
\hline & 4 型 & $: 7$ \\
\hline \multirow[t]{5}{*}{ 占居部位 } & $\mathrm{Ce}$ & $: 2$ \\
\hline & Iu & $: 14$ \\
\hline & $\operatorname{Im}$ & $: 85$ \\
\hline & $\mathrm{Ei}$ & $: 19$ \\
\hline & $\mathrm{Ea}$ & $: 6$ \\
\hline \multirow[t]{4}{*}{ 深達度 } & $\mathrm{a} 0$ & $: 48$ \\
\hline & al & $: 49$ \\
\hline & a2 & $: 24$ \\
\hline & a3 & $: 5$ \\
\hline \multirow[t]{5}{*}{ 転移リンパ節群 } & no & $: 42$ \\
\hline & nl & $: 9$ \\
\hline & $\mathrm{n} 2$ & $: 37$ \\
\hline & n3 & $: 27$ \\
\hline & $\mathrm{n} 4$ & $: 11$ \\
\hline \multirow[t]{4}{*}{ 転移リンパ節個数 } & 0 個 & $: 42$ \\
\hline & $1 \sim 3$ 個 & $: 42$ \\
\hline & $4 \sim 7$ 個 & $: 26$ \\
\hline & 8 個以上 & $: 16$ \\
\hline
\end{tabular}

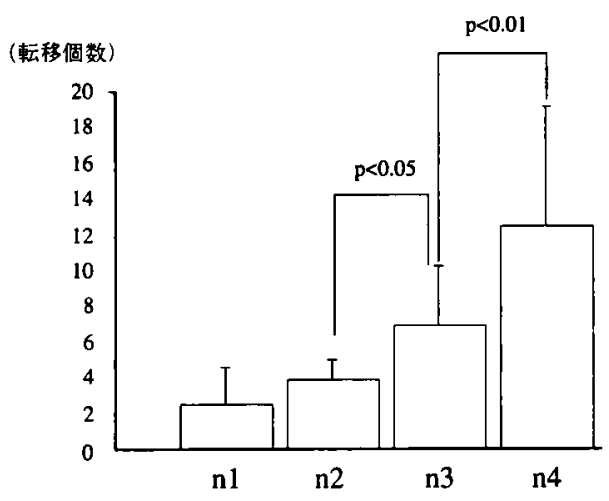

図 1 転移リンパ節群別の轻移個数

\section{3）転移リンパ節群と生存率}

転移リンパ節群別の生存率は $\mathrm{n} 2, \mathrm{n} 3$ 間で差 $(\mathrm{p}<$ 0.01）を認めたが，n0，n1間や n1，n2間および，n3, $\mathrm{n} 4$ 間では差を認めなかった。 5 年生存率は $\mathrm{n} 2$ 群では $36.7 \%$ に対してn3群では 5 年生存例を現在認めてお らず, 3 年生存率でも $5.7 \%$ と著しく予後不良であった
(図 2).

\section{4）転移リンパ節個数と生存率}

転移リンパ節個数別の生存率は, 0 個群と $1 \sim 3$ 個 群間 $(\mathrm{p}<0.01)$ 扔よび $1 \sim 3$ 個群と 4 7 個群間 $(\mathrm{p}<$ $0.05)$ で差を認め, 5 年生存率は, 0 個群で $45.2 \%$, $1 \sim 3$ 個群で31.8\%に対し $4 \sim 7$ 個群では $16.6 \%, 8$ 個以上群では 5 年生存例を認めなかった（図 3 ).

5）n1ないしは n2症例におけるリンパ節転移個数別 の生存率

比較的予後良好と考えられるn1ないしは 2 症例 (42例) 間においても 4 7 個群 (13例) は $1 \sim 3$ 個群 （29例）に比べ差を認めた $(\mathrm{p}<0.05) .5$ 年生存率は 1 〜 3 個群が, $48 \%$ に対して 4 〜 個群は $26.9 \%$ とリン パ節転移が，比較的近傍に留まっている症例でも転移 個数の多い症例は予後不良であった（図4）。

6）n3ないしは 4 症例におけるリンパ節転移個数別 の生存率

元来予後不良の $\mathrm{n} 3$ ないしは $\mathrm{n} 4$ 症例（38例）において は転移個数群間に差を認めなかった。 5 年生存率では 1〜3 個群(13例) で1.3\%，4〜 7 個群(13例)で9.6\%, 8 個以上群 (12例) では 5 年生存例を認めなかった. すなわち遠隔リンパ節転移群では転移個数にかかわら

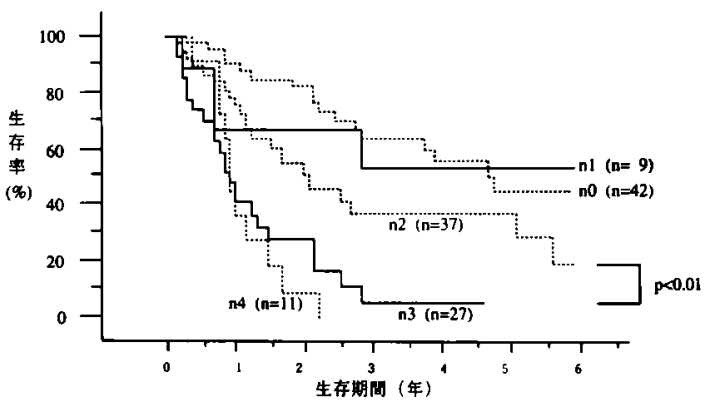

図 2 転移リンパ節群別の生存率

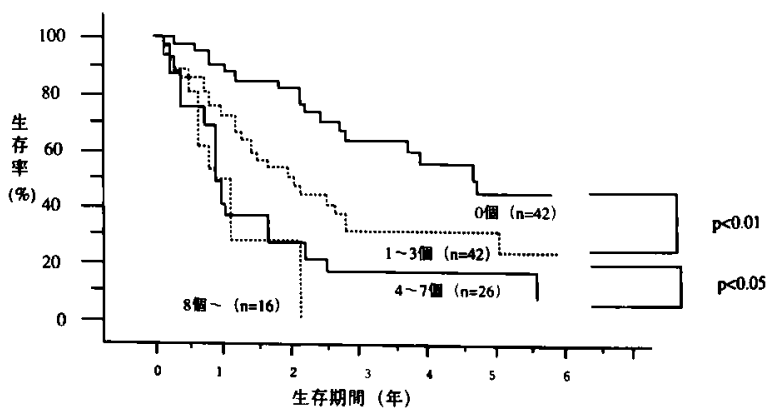

图 3 リンパ節転移個数別の生存率 
ず予後不良であった（図５）。

7) リンパ節転移個数と再発形式

再発は，126例中80例 (63.5\%) に認められ，その再 発形式をリンパ節再発, 臓器再発, リンパ節十臟器の 重複再発, その他（局所, 播種, 吻合部）に分類して 転移個数別に検討した。転移個数 4 個以上では，42例 中34例 $(81 \%)$ の症例に再発を認め, 転移個数の増加 にともない再発例が増加した．再発形式は，リンパ節 転移陽性例では，転移個数に限らず，リンパ節再発が 多かった．また，転移個数 0 個の症例でも 42 例中19例 (45.2\%)に再発を認めたが，血行性転移による臟器再

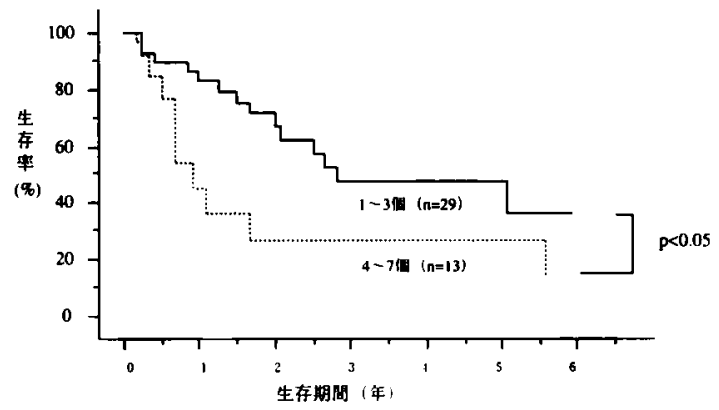

図4n1ないしはn2症例におけるリンパ節転移個数 別の生存率

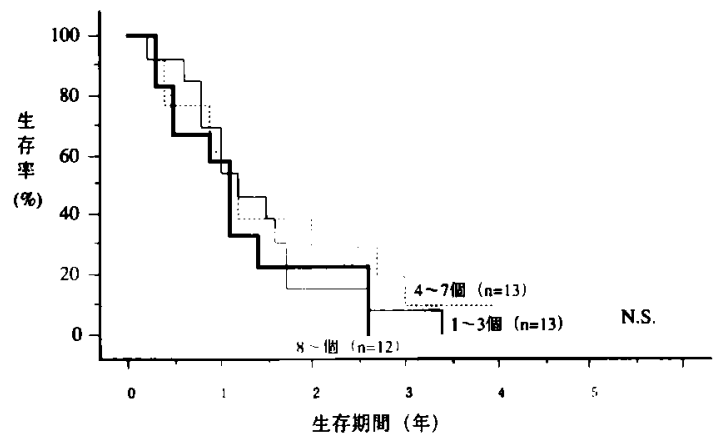

図 5 n3ないしはn4症例におけるリンパ節転移個数 別の生存率
発が8例（19\%）と最も多かった（表 $2 ）$.

\section{8）予後因子と多变量解析}

年齢, 性差, 肉眼型, 占居部位, 深達度, 転移リン パ節群, 転移リンパ節個数の 7 因子についての Logrank 法を用いた単変量解析では占居部位を除く他の 6 因子が統計学的に有意であった.さらに Cox の比例 ハザードモデルを用いた多変量解析では, 転移リンパ 節群 $(p=0.0084)$, 転移リンパ節個数 $(\mathrm{p}=0.0018)$ が 独立した予後因子であった。なお，今回，転移リンパ 節群と転移リンパ節個数が，互いに予後に関して影響 を及ほすため, 各々別々に多変量解析を行った。

多変量解析の結果より，予後に関して転移リンパ節 個数は最も重みのある因子と考えられた（表 3 ）。

\section{考察}

食道癌手術症例のリンパ節転移の有無は重要な予後 規定因子であることは，従来より認められているが， リンパ節転移の予後に対する評価方法として現行の規 約)では，転移リンパ節群による転移の範囲のみによ り評価されている2131. 今回の,われわれの検討では, 5 年生存率は $\mathrm{n} 2$ 群で36.7\%に対してn3群では, 3 年 生存率でも5.7\%と著しく予後不良であった，全国登 録6)の結果でも 5 年生存率は $\mathrm{n} 2$ 群では $14.2 \%$ に対して $\mathrm{n} 3$ 群では5.2\%と著しく予後不良で, 規約上"でも，n3， $\mathrm{n} 4$ を遠隔りンパ節群とし $\mathrm{n} 1, \mathrm{n} 2$ と区別して取り扱って (る6).リンパ節転移に関して, 転移リンパ節群から見 た予後の評価は，経験上，理にかなった定義と考えら れる.一方，臨床の場において，遠隔リンパ転移は認

表 3 食道癌における予後因子

\begin{tabular}{|c|c|c|c|}
\hline & 单変量解析 & \multicolumn{2}{|c|}{ 多変量解析 } \\
\hline 年齿 $(<65$ vs $\geqq 65)$ & $p=0.0384$ & $p=0.2490$ & $p=0.1320$ \\
\hline 性別 & $p=0.0419$ & $p=0.3779$ & $p=0.1717$ \\
\hline 肉眼型 & $p=0.0044$ & $p=0.7869$ & $p=0.3129$ \\
\hline 占拠部位 & $p=0.9139$ & $p=0.9773$ & $p=0.9038$ \\
\hline 深達度 & $p<0.0001$ & $p=0.1466$ & $p=0.0949$ \\
\hline 転移リンパ節群 & $p<0.0001$ & $p=0.0084$ & - \\
\hline 転移リンパ節個数 & $\mathrm{p}<0.0001$ & - & $p=0.0018$ \\
\hline
\end{tabular}

表 2 転移個数と再発形式

\begin{tabular}{c|c|c|c|c|c}
\hline 転移個数 & リンパ節再発 & 蔵器再発 & リンパ節+蔵器再発 & その他 & 計 \\
\hline 0 & 4 & 8 & 3 & 4 & 19 \\
$(n=42)$ & $(9.5 \%)$ & $(19 \%)$ & $(7 \%)$ & $(9.5 \%)$ & $(45 \%)$ \\
$1 \leqq n \leqq 3$ & 11 & 7 & 6 & 3 & 27 \\
$(n=42)$ & $(26 \%)$ & $(17 \%)$ & $(14 \%)$ & $(7 \%)$ & $(64 \%)$ \\
$4 \leqq n$ & 12 & 9 & 12 & 1 & 34 \\
$(n=42)$ & $(29 \%)$ & $(21 \%)$ & $(29 \%)$ & $(2 \%)$ & $(81 \%)$ \\
\hline
\end{tabular}


めないものの，多数のリンパ節転移を有する症例を 時々経験し，そのような症例の予後の評価は，やはり 気になるところである。

近年，転移リンパ節個数も重要な予後因子と報告さ れ2)ー4，また，新規規約案占においても転移リンパ節個 数は病期分類に加味されている.乳癌，大腸癌などの TNM 分類では, 既に, 転移個数が病期分類に加味され ている7、種々の鳏腫における転移個数と予後に関す る報告では,転移個数 4 〜 個を cut off 值として差を 認めるとする報告が多( ${ }^{6)-8)}$. 同様に, 食道癌について も，4〜5個までは, 広範囲りンパ節郭清と集学的療 法により長期予後が期待できるとの報告が多い ${ }^{314) 99}$. なお，欧米の報告では，Skinner ら(0)は，a0ならば，4 個までのリンパ節転移は enbloc な切除が予後を向上 させるとしている，今回の検討では，転移リンパ節個 数を新規約案古に従って 4 群に分類し予後の検討を 行ったが， 5 年生存率は， 0 個の群で $45.2 \% ， 1 \sim 3$ 個の群で31.8\%に対し，4〜 7 個群では $16.6 \% ， 8$ 個 以上群ては 5 年生存例を認めず，他の報告の如く転移 個数 4 個以上の予後は不良であった。 また，転移個数 と転移リンパ節群の関係については概ね相関傾向を認 めたが, n1あるいは n2症例の 46症例のうち，転移個数 4 個以上の症例が 17 例も存在し，それらの 5 年生存率 は 1〜3 個の群で $48 \% ， 4 〜 7$ 個の群で $26.9 \%$ とリン 八節転移か，比較的近傍に留まっている症例において も転移個数の多い症例の予後は不良であった．転移個 数の多い症例では, 転移領域が多領域に拡がる傾向が 強くなり予後不良の原因となるとされている233)．この 傾向は, われわれの $\mathrm{n} 1, \mathrm{n} 2$ 症例でも確認された。一方, n3ないしはn4などの遠隔りンパ節転移症例は転移個 数にかかわらず予後不良であり，このような症例は既 に全身病の状態であると推察される。

再発形式に関しては, 剖検例の報告で上縦隔, 頸部 リンパ節の頻度が高いことを指摘されてきた ${ }^{11122}$. 今 回検討した126例のうち80例に再発を認め，その内訳 は, リンパ節再発27例, 缄器再発24例, 重複再発21例, その他 8 例であった。この結果は，他の報告とほほ同 様(゙'1314)，食道癌においてリンパ節転移の予後に及ぼ す影響の大きさを裏付けるものであった。一方，n0症 例においても42例中19例に再発を認めたが，その多く が，血行性転移による葴器再発であったが，リンパ節 再発（重複再発を含む）も認められ，その 7 例中 4 例 が頙部ないし上緥隔リンパ節再発であった。 $\mathrm{n} 0$ 症例で あっても，リンパ節再発の報告も多く認められ，その
多くは頸部ないし上綎隔リンパ節再発であり, 同部位 でのリンパ節郭清の重要さが示唆された15116).

これらのことより食道癌の予後に関してリンパ節転 移個数は重要な因子と考えられたが，食道癌の予後に 関して樑達度 (a 因子)も含めた他の因子とリンパ節転 移との比較検討もあり ${ }^{9117)}$, 今回, 他の予後に関する因 子との比較検討を進めた。年齢, 性差, 肉眼型, 占居 部位, 深達度, 転移リンパ節群, 転移リンパ節個数の 7 因子についての Logrank 法を用いた単変量解析で は占居部位を除く他の 6 因子が統計学的に有意であっ た. 更に, 食道癌の予後解析には Cox の比例ハザード モデルが,最も適している ${ }^{18)}$ との報告もあることより， これを用いて多変量解析を行ったが $\left.{ }^{19}\right)$, 転移個数( $(\mathrm{p}=$ 0.0018）が，予後に結びつく因子として最も重みのあ る因子と考えられる結果となった。

今回の検討より，食道癌において転移リンパ節個数 は, 最も重要な予後規定因子と考えられ, 食道癌術後 の予後の重要な指標と考えられた。

\section{結 語}

1）食道癌の予後を規定する因子として転移リンパ 節個数は最も重要な因子と考えられた。

2）リンパ節転移が, 比較的近傍に留まっている症例 でも転移個数の多い症例は予後不良であり，食道癌術 後も注意深い経過観察を要することが, 示唆された。

なお，本論文の要旨は第27回癌とリンパ節研究会におい て発表した。

\section{文献}

1）食道疾患研究会編：食道癌取扱い規約. 改訂第 8 版，金原出版，東京，1992

2）夏越洋次，島津久明，馬場政道地：胸部食道癌に対 する 3 領域りンパ節郭清後の再発に関する検討. 日消外会誌 $24: 2888-2893,1991$

3）安藤暢敏, 篠沢洋太郎, 森雄他: 食道癌のリン 八節転移程度と予後. Karkinos 4: 1079-1088, 1991

4）馬場政道, 吉中平次, 田辺 元他：胸部食道癌の転 移リンパ節個数の検討. 日消外会誌 21：20692074,1988

5）食道疾䁇研究会編：日本食道疾患研究会委員会活 動報告集. 日本食道疾患研究会事務局, 東京, 1997

6）藤田博正, 掛川暉夫, 安藤啺敏他：食道癌切除例の リンパ節転移に関する定量的および定性的解析. 日外会誌 $86: 424-434,1985$

7) International Union Against: $T M N$ classification of malignath tumors 4 th ed. 
Springer-Verlag, New York, 1987

8）朴常秀, 中根恭司, 大草世雄他：胃癌におけるリ ンパ節転移度, リンパ節個数の検討. 日消外会誌 $23: 841-850,1990$

9）加藤抱一, 渡辺 寛, 飯塚紀文他：食道癌のリンパ 節転移と治療成績. 日消外会誌 $22: 1729-1737$, 1989

10) Skinner DB, Ferguson ML, Little AG, et al: Selection of operation for esophageal cancer based on staging. Ann Surg 204: 391-401, 1986

11）渡辺 寛, 加藤抱一, 飯塚紀文 : 治病切除食道癌の 再発形式に閔する検討. 日消外会誌 18：19731979,1985

12）藤田博正：食道癌切除症例の再発形式に関する検 討(剖検例を中心に). 日外会誌 $85: 17-28,1984$

13）西平哲朗, 大森典夫, 平山 克他：胸部食道浮根治 手術における頝部リンパ節郭清の意義 (Iu, Im, Ei
症例において)。外科診療 $28: 549-554,1986$

14）杉町圭蔵, 上尾裕昭, 奥平恭之他：食道澏の再発形 式とその予防対策. 外科治㙩 $47: 6-12,1982$

15）西 満正, 松原敏樹,木下 䈣他：リンパ節転移か らみた胸部食道癌の予後と再発形式. 消外 9 ： $1597-1605,1986$

16）小野澤君夫, 鍋谷欣市, 加来朝王他：食道表在癌再 発例の検討。杏林医会誌 $19: 433-437,1988$

17) 大森典夫：胸部食道癌のリンパ節転移と予後(特 に転移リンパ節数及び胸腔内転移，腹腔内転移に ついて). 日外会誌 $88: 413-421,1987$

18）佐藤美晴, 浜辺 豊, 斎藤陽一：予後因子からみた 食道癌悪性度の評価。日消外会誌 $18: 576-580$, 1985

19）篠原昌司，松原義弘：比例ハザードモデルとその 周辺. 応用統計学 $11: 1-23,1982$

\title{
A STUDY ON THE NUMBER OF METASTATIC LYMPH NODES AND PROGNOSIS OF PATIENTS WITH ESOPHAGEAL CANCER
}

\author{
Kouji EMOTO, Akihiko WATANABE, Hidetomo SAWADA, Yukishige YAMADA, \\ Mitsutoshi TATSUMI, Teruyuki SAKAGUCHI, Heisuke FUJIMOTO, \\ Michihiro NARIKIYO, Tomoko HIRAO and Hiroshige NAKANO \\ First Department of Surgery, Nara Medical University
}

One handred and twenty six patients with esophageal cancer underwent esophagectomy with more than R2 lymph node dissection at the Nara medical universty hospital, were studied on the effects on prognoses of the n-number and number of metastatic lymph nodes, and a multivariate analysis including other prognostic factors was made.

Concerning the n-number, a statistically significant difference was noted in survival rate between $\mathrm{n} 2$ $(+)$ and $n 3(+)$. As to the number of metastatic lymph nodes, the patients were classified into four groups, i.e. none (group a), one to three (group B), four to seven (group $\mathrm{C}$ ) and more than eight positive lymph nodes (group D). There were significant differences in the survival rate between group $A$ and group $B$, and group $\mathrm{B}$ and group $\mathrm{C}$. Furthermore, limiting the cases of $\mathrm{n} 1(+)$ or $\mathrm{n} 2(+)$, group $\mathrm{C}$ obtained a significantly longer survival time than group $\mathrm{D}$. It means that the patients with many positive lymph nodes have poor prognoses, even though these metastases are confined to relatively near the original tumors. In a multivariate analysis of seven factors including age, sex, macroscopical type, location, depth of cancer invasion, the n-number, and number of metastatic lymph nodes, the last factor has turned out to be the most connected with the prognosis. It is concluded that the number of metastatic lymph nodes is the most important prognostic factor in patients with esophageal cancer. 